\title{
Fatal Intracranial Hemorrhage as the Initial Presentation of Acute Lymphocytic Leukemia: A Case Report
}

\author{
Akut Lenfositik Löseminin İlk Bulgusu Olarak Ölümcül İntrakraniyal \\ Kanama: Bir Olgu Sunumu
}

Shashikant PATIL, Ali NOURBAKHSH, Jai Deep THAKUR, Imad Saeed KHAN, Bharat GUTHIKONDA

Louisiana State University Health Science Center, Department of Neurosurgery, Shreveport, USA

Corresponding Author: Bharat GUTHIKONDA / E-mail: bguthi@1suhsc.edu

\begin{abstract}
Hemorrhagic complications of acute leukemia are well described and are a common cause of mortality in these patients. However, to our knowledge, fatal intracerebral hemorrhage $(\mathrm{ICH})$ as an initial presentation of acute lymphocytic leukemia (ALL) has only been reported once. We report a case of previously undiagnosed ALL presenting with $\mathrm{ICH}$. Our patient is a 17-year old male who was found unresponsive several hours after complaining of headache. Initial emergency room evaluation found the patient to have anisocoria with a fixed and dilated right pupil and demonstrated evidence of decorticate posturing. Imaging revealed a large right-sided intraparenchymal hemorrhage, intraventricular hemorrhage, midline shift, and uncal herniation. Laboratory evaluation showed marked leukocytosis with blastic predominance and evidence of disseminated intravascular coagulopathy. Emergent surgical intervention was performed. However, despite evacuation of the hematoma, the patient eventually progressed to clinical brain death. Usually, ICH is seen in ALL patients after the diagnosis has been made. We report a unique case of fatal intracranial hemorrhage as the initial presentation of ALL and discuss the possible management dilemmas to treat such entities. ALL should be kept in the broad differential diagnosis of spontaneous $\mathrm{ICH}$, especially in a young patient with evidence of severe coagulopathy.
\end{abstract}

KEYWORDS: Acute lymphocytic leukemia, Disseminated intravascular coagulation, Subarachnoid hemorrhage, Intracerebral hemorrhage

öz

Akut löseminin hemorajik komplikasyonları iyice tanımlanmıştır ve bu hastalarda mortalitenin sık görülen bir nedenidir. Ancak bildiğimiz kadarıyla akut lenfositik löseminin (ALL) başlangıç bulgusu olarak ölümcül intraserebral kanama sadece bir kez bildirilmiştir. İntraserebral kanama ile gelen ve önceden tanı konmamış bir ALL tanısı sunuyoruz. Hastamız 17 yaşında bir erkekti ve baş ağrısından yakındıktan birkaç saat sonra tepki göstermez bir şekilde bulundu. Acil servisteki başlangıç değerlendirmesi hastada anizokori ve sabit ve dilate sağ pupil saptadı ve dekortike postür bulguları mevcuttu. Görüntüleme büyük bir sağ taraflı intraparenkimal kanama, intraventriküler kanama, orta hatta kayma ve unkal herniasyon gösterdi. Laboratuvar değerlendirmesi blast predominansı ile belirgin lökositoz ve dissemine intravasküler koagülopati bulguları gösterdi. Hemen cerrahi girişim yapıldı. Ancak hematom boşaltılmasına rağmen hasta hızla klinik beyin ölümüne ilerledi. İntraserebral kanama, ALL hastalarında genellikle tanı konduktan sonra saptanır. ALL'nin ilk bulgusu olarak ölümcül intrakraniyal kanama görülen benzersiz bir vaka bildiriyor ve bu tür vakaları tedavi etmekte olası ikilemleri tartışıyoruz. ALL özellikle şiddetli koagülopati bulgusu olan genç hastalarda spontan intraserebral kanamanın ayırıcı tanısında dikkate alınmalıdır.

ANAHTAR SÖZCÜKLER: Akut lenfositik lösemi, Dissemine intravasküler koagülasyon, Subaraknoid kanama, İntraserebral kanama

\section{INTRODUCTION}

It is well known that lymphoid or myeloid leukemic cells may infiltrate the CNS and lead to patchy or solid metastatic deposits. This may be due to the primary effect of the malignancy or may be secondary to the myelosuppressive nature of the disease treatment $(1,10,15)$. Some of the chemotherapeutic regimens for Acute Lymphocytic Leukemia (ALL) such as methotrexate or L-asparaginase, may lead to heightened risk of CNS hemorrhage $(6,17)$. Disseminated intravascular coagulation $(\mathrm{DIC})$ is a serious complication of a variety of benign and malignant diseases. Among subtypes of acute leukemias, acute promyelocytic leukemia (APL) is most frequently complicated by serious, often life-threatening DIC; however, all leukemias can be complicated by DIC $(7,5)$.

$\mathrm{ICH}$ is the second most common cause of mortality in ALL after infection (5). Addressing the correctable factors involved in the pathophysiology of $\mathrm{ICH}$ is important given the fact that these patients might still be actively bleeding at the time of presentation and have fairly high chances of re-bleed if the underlying factors are not corrected. Therefore, in these clinical scenarios where the treatment plan and its execution have to be formulated quickly and where evidence based 
treatment strategies are lacking, management becomes a great challenge. We present a rare case whose clinical course was unfortunately fatal and review the literature for better understanding of underlying pathophysiology of the intracerebral hemorrhage and various management options.

\section{CASE REPORT}

Our patient is a 17-year-old male without significant past medical history who was found to be unresponsive by family members in his home. A few hours earlier, the patient had complained of a severe headache and went to lie down in a dark room. He was intubated in the field and brought emergently to the emergency room. On initial evaluation, he was unresponsive. He had anisocoria with a fixed / dilated right pupil. He showed evidence of decorticate posturing to deep painful stimulation and had GCS of $5 \mathrm{t}$.

Complete blood count $(C B C)$ revealed findings consistent with ALL with blast crisis. The white blood cell (WBC) count was $746,000 / \mathrm{mm} 3 ; 65 \%$ were blasts and $31 \%$ were lymphocytes; these cells were mainly atypical in appearance (Figure 1). The coagulation profile was consistent with disseminated intravascular coagulation (DIC) (Table I). Computed tomography (CT) scan of the brain without contrast showed a large $(5 \times 8 \mathrm{~cm})$ right fronto-temporoparietal intraparenchymal hematoma with significant midline shift. There was significant edema around the hemorrhage and evidence of resulting uncal herniation with obliteration of the basal cisterns (Figure 2).

Given the patient's young age and the fact that some motor and brainstem function was still present, we decided to take him emergently to the operating room despite the hematological evidence of DIC. Fresh frozen plasma, platelet, and packed red blood cell transfusions were given throughout the perioperative period. We performed a large right-sided decompressive hemicraniectomy and evacuated the intracerebral hemorrhage. As expected, the brain was markedly swollen and no attempt was made to close the dura or replace the bone flap. The right hemisphere appeared dusky

Table I: Complete Blood Count (CBC) and Coagulation Profile of the Patient

\begin{tabular}{|l|l|l|}
\hline Laboratory Test & Patient & Normal \\
\hline White blood count & $55.13 \mathrm{~K} / \mathrm{uL}$ & $4.5-13.0 \mathrm{~K} / \mathrm{uL}$ \\
\hline Red blood count & $2.09 \mathrm{M} / \mathrm{uL}$ & $4.5-5.3 \mathrm{M} / \mathrm{uL}$ \\
\hline Hemoglobin & $5.9 \mathrm{G} / \mathrm{dL}$ & $13.0-16.0 \mathrm{G} / \mathrm{dL}$ \\
\hline Platelet & $12 \mathrm{~K} / \mathrm{uL}$ & $142-405 \mathrm{~K} / \mathrm{uL}$ \\
\hline Prothrombin time & $17.7 \mathrm{SEC}$ & $11.3-15.2 \mathrm{SEC}$ \\
\hline INR & 1.46 & \\
\hline Activated PTT & $28.5 \mathrm{SEC}$ & $24.7-35.5 \mathrm{SEC}$ \\
\hline Fibrinogen & $204 \mathrm{mg} / \mathrm{dL}$ & $214-451$ \\
\hline D-Dimer & $7.71 \mathrm{uG} / \mathrm{mL}$ & $<0.5$ \\
\hline
\end{tabular}

dl: deciliter, K: Kilo, M: million, $\mathbf{m g}$ : milligram, $\boldsymbol{m l}$ : milliliter, uG: microgram, ul: micro liter, SEC: seconds. and did not regain pulsatility despite emergent evacuation of the hemorrhage. Despite aggressive surgical and medical management, the patient quickly lost brainstem reflexes and progressed to clinical brain death within hours after surgery.

\section{DISCUSSION}

Neurologic complications of acute leukemia as the primary consequence of malignancy or as secondary complications

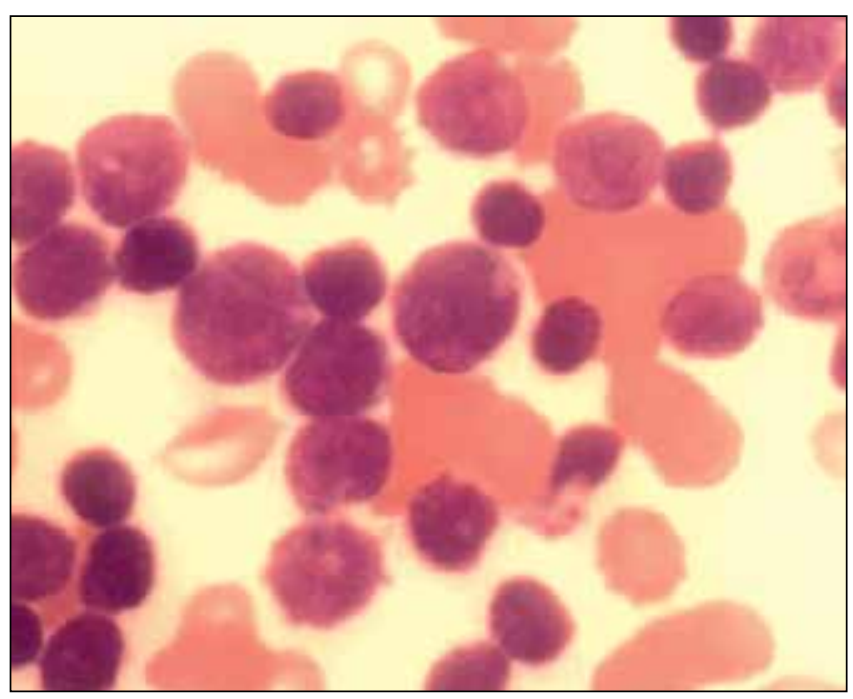

Figure 1: Blood smear of the patient, showing lymphoblasts with a high ratio of nuclear to cytoplasmic ratio.

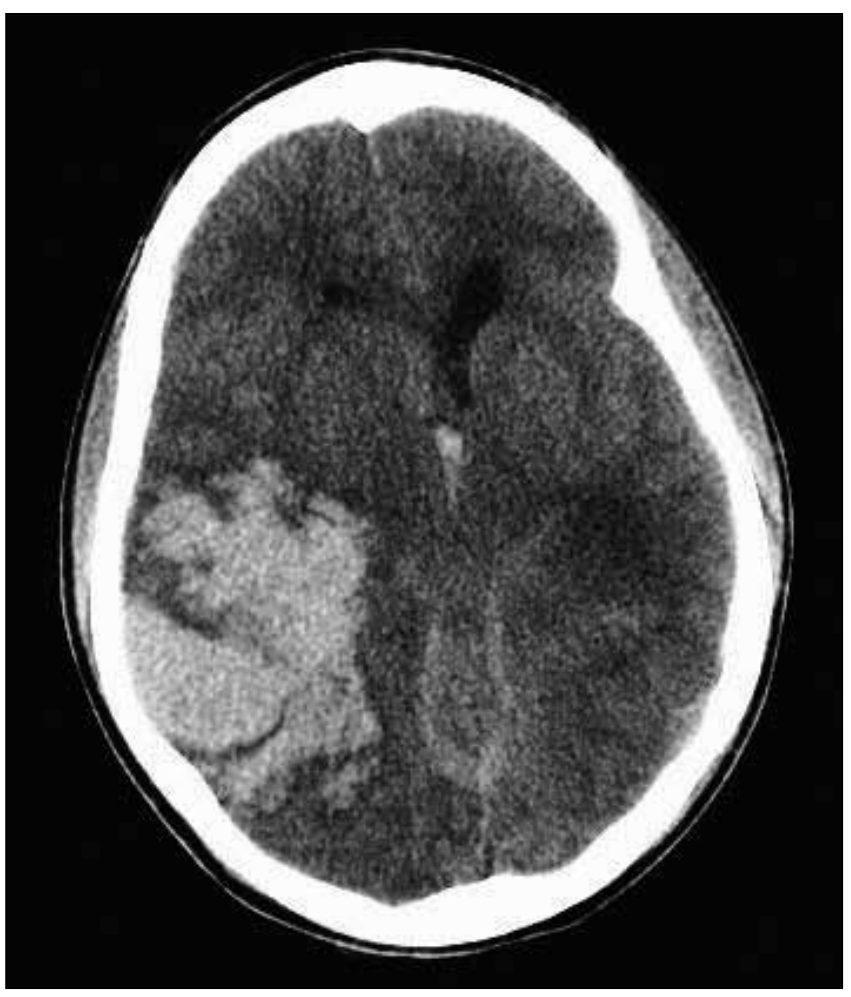

Figure 2: Computed tomographic (CT) image, axial cut of the patient showing a massive intraparenchymal hemorrhage in the right hemisphere. 
of chemotherapy are well described and can be potentially serious $(1,10,18)$.

Intracranial sequelae include leukemic infiltration (chloroma), miliary intracerebral hemorrhage, acute hemorrhagic leukoencephalitis, intracranial fungal infection. Ischemic consequences can be precipitated by leukemia induced vasculitis or venous thrombosis. Chou et al described two patients with acute myelogenous leukemia who had miliary cerebral hemorrhages (2). Sakai et al. reported a case of acute myelocytic leukemia (AML) in which the initial presentation of the patient was with intracranial hemorrhage (14). The autopsy showed massive hemorrhage in the right putamen with ventricular rupture that displaced the right thalamus to the left. Pagano et al described the incidence of CNS complications in patients with $\mathrm{AML}$ to be $\sim 8 \%$, with most cases related to leukemic infiltration or hemorrhage ${ }^{13}$. They reported 3 cases of acute hemorrhagic leukoencephalitis due to AML following hematological remission. All three of these patients developed a severe neurologic syndrome that rapidly evolved into coma and death. Kim et al. reported 41 fatal intracranial hemorrhages among 792 acute leukemia patients (9). The most common type was acute promyelocytic leukemia (44\%). Cerebral parenchyma was the region most commonly involved followed by cerebellar parenchyma and the subdural space. In Kawanami et al's series, histopathological examination of the acute leukemic patients showed hemorrhagic infarction due to disseminated fungal infection ( 5 cases after chemotherapy, one of which was ALL), multiple hemorrhages $(<2 \mathrm{~cm})$ due to leukemic cell infiltration ( 2 cases) and a single massive hemorrhage with petechial hemorrhages in various regions of the brain (4 cases) due to AML coagulopathy (thrombocytopenia or DIC) (8). Clinicopathological correlation revealed that fungal disseminations occurred under agranulocytosis, while leukemic cell infiltration occurred under a marked leukocyotosis (peripheral white blood cell count $>100,000 / \mu \mathrm{l}$ ). The results of several studies showed that that DIC is found in about $10 \%$ of adult patients with ALL at diagnosis $(15,16)$.

CD34 is expressed on hematopoietic stem cells and also on about $60-70 \%$ of ALL blasts of both adults and children (15). An etiological link between CD34 expression in common ALL patients and DIC was suggested in Higuchi et al.'s study (7). White blood cell count of the ALL patients presenting with DIC was found to be higher (up to $400,000 / \mu l$ ) than non-DIC patients. According to Higuchi et al, there was no difference in lactate dehydrogenase (LDH) level, percentage of blasts in bone marrow, or frequency of lymphadenopathy or hepatomegaly between DIC and non-DIC ALL patients. As expected, platelet counts were lower and fibrinogen/fibrin degradation products were higher in DIC patients (7).

Marked leukocytosis, thrombocytopenia and blast crises are significant risk factors for multiple cerebral hemorrhages in acute leukemias (8). Freireich et al. mentioned that histopathologically, perivascular leukemic infiltrates are often seen around the hemorrhagic foci (4). Aggregated leukemic cells cause damage to the vascular endothelial cells, resulting in hemorrhage (4). Another explanation for CNS bleeding is vascular wall damage by the direct invasion of leukemic cells (3). It is believed that marked leukocytosis results in hyperviscosity, leukostasis, hypoxic vasodilatation, and eventual rupture of small cerebral vessels, resulting in various sized intracerebral hemorrhages (2).

Even though the incidence of $\mathrm{ICH}$ in ALL as an initial sign might be more than what is reported, we would like to highlight the scarcity in the literature for management of these clinical scenarios. The concept of treating this clinical entity as a regular $\mathrm{ICH}$ commends precaution. The frequently cited STICH trial (11) is the largest existing trial for $\mathrm{ICH}$; this study suggests that early evacuation of spontaneous supratentorial $\mathrm{ICH}$ shows no overall benefit when compared with initial conservative (non operative) treatment. However their results warrant a cautious interpretation. In their trial, poor outcome was seen in patients with GCS $\leq 8$ and early surgery was seen to increase the relative risk of poor outcome for these patients by $8 \%$. Further, the study suggested favorable outcomes from early surgery in patients with GCS 9-12 and having hematoma within $1 \mathrm{~cm}$ or less from the cortical surface. This has been able to establish an agreement in the literature.

Stating that early surgery is the most reasonable answer for a patient presenting with spontaneous supratentorial $\mathrm{ICH}$, whose GCS is between 9-12 and hematoma is located within $1 \mathrm{~cm}$ of the cortical surface needs a possible revisiting, as far as dealing with ALL patients which present as ICH as their initial presentation. This difference may be attributed to the variation in pathophysiology of the intracranial bleed in ALL patients compared to other causes of $\mathrm{ICH}$, as discussed earlier. Recently, Naunheim et al reported a similar case where an undiagnosed ALL patient presented with subdural hematoma, sub-arachnoid hemorrhage and two contiguous frontal parenchymal hemorrhages of $4.3 \mathrm{~cm} \times 1.6 \mathrm{~cm}$ and 2.9 $\mathrm{cm} \times 2.7 \mathrm{~cm}$ (12). The patients GCS was 9t on admission. He was thrombocytopenic, had developed blast crises and was managed medically along with leukophoresis to address high leukocyte count and eventually patient's neurological status improved and made a good recovery. In contrast to this case, our patient had an unfortunate fatal course where surgery was the only possible salvage option for a young patient with a clot located within $1 \mathrm{~cm}$ of cortical surface and clinical syndrome of uncal herniation.

This case shows that massive cerebral bleeding can occur as a result of DIC due to ALL. Extreme leukocytosis and coagulopathy led to fatal intracerebral and intraventricular bleeding in this patient. The possibility of DIC should always be ruled out in leukemic patients that can be a potential cause of intracranial bleeding. This report represents a unique presentation of ALL and indicates that leukemia with DIC should be included in the broad differential diagnosis of spontaneous intracerebral hemorrhage, especially in the pediatric population. 


\section{REFERENCES}

1. Bleyer WA: Central nervous system leukemia. Pediatr Clin North Am 35:789-814, 1988

2. Chou SH-Y, Singhal AB: Multiple punctate cerebral hemorrhages in acute leukemia with blast crisis. Neurology 68:953, 2007, 10.1212/01.wnl.0000257151.61125.51

3. Creutzig U, Ritter J, Budde M, Sutor A, Schellong G: Early deaths due to hemorrhage and leukostasis in childhood acute myelogenous leukemia. Associations with hyperleukocytosis and acute monocytic leukemia. Cancer 60:3071-3079, 1987

4. Freireich EJ, Thomas LB, Frei E 3RD, Fritz RD, Forkner Ce JR: A distinctive type of intracerebral hemorrhage associated with "blastic crisis" in patients with leukemia. Cancer 13:146-154, 1960

5. Faderl S, Jeha S, Kantarjian HM: The biology and therapy of adult acute lymphoblastic leukemia. Cancer 98:1337-1354, 2003, 10.1002/cncr.11664

6. Graus F, Saiz A, Sierra J, Arbaiza D, Rovira M, Carreras E, et al: Neurologic complications of autologous and allogeneic bone marrow transplantation in patients with leukemia: A comparative study. Neurology 46:1004-1009, 1996

7. Higuchi T, Mori H, Niikura H, Omine M, Okada S, Terada H: Disseminated intravascular coagulation in acute lymphoblastic leukemia at presentation and in early phase of remission induction therapy. Ann Hematol 76:263-269, 1998

8. Kawanami T, Kurita K, Yamakawa M, Omoto E, Kato T: Cerebrovascular disease in acute leukemia: A clinicopathological study of 14 patients. Intern. Med 41:1130-1134, 2002

9. Kim H, Lee JH, Choi SJ, Kim WK, Lee JS, Lee KH: Analysis of fatal intracranial hemorrhage in 792 acute leukemia patients. Haematologica 89:622-624, 2004

10. Marra R, Pagano L, Storti S, Leone G, Accorrà F, Bizzi B: Solid leukemic intracerebral deposits in patients with acute leukemia. Haematologica 71:303-306, 1986
11. Mendelow AD, Gregson BA, Fernandes HM, Murray GD, Teasdale GM, Hope DT, Karimi A, Shaw MD, Barer DH: Early surgery versus initial conservative treatment in patients with spontaneous supratentorial intracerebral haematomas in the International Surgical Trial in Intracerebral Haemorrhage (STICH): A randomised trial. Lancet 365:387-397,2005, 10.1016/S0140-6736(05)17826-X

12. Naunheim MR, Nahed BV, Walcott $B P$, Kahle $K T$, Soupir $C P$, Cahill DP, et al: Diagnosis of acute lymphoblastic leukemia from intracerebral hemorrhage and blast crisis. A case report and review of the literature. Clin Neurol Neurosurg 112: 575-577, 2010, 10.1016/j.clineuro.2010.04.001

13. Pagano L, Larocca LM, Vaccario ML, Masullo C, Antinori A, Pierconti F, Tartaglione T, Cattani P, Mele L, Equitani F, Leoneet $\mathrm{G}$ : Acute hemorrhagic leukoencephalitis in patients with acute myeloid leukemia in hematologic complete remission. Haematologica 84:270-274, 1999

14. Sakai K, Takatsu A, Shigeta A, Abe S, Ikegami M, Takagi K: Sudden death due to undiagnosed acute promyelocytic leukemia: A case report. Int J Legal Med 121:311-314, 2007, 10.1007/s00414-006-0106-X

15. Sarris AH, Kempin S, Berman E, Michaeli J, Little C, Andreeff M, Gee T, Straus D, Gansbacher B, Filippa D: High incidence of disseminated intravascular coagulation during remission induction of adult patients with acute lymphoblastic leukemia. Blood 79:1305-1310, 1992

16. Sarris A, Cortes J, Kantarjian H, Pierce S, Smith T, Keating M, Koller C, Kornblau S, O'brien S, Andreeff M: Disseminated intravascular coagulation in adult acute lymphoblastic leukemia: Frequent complications with fibrinogen levels less than $100 \mathrm{mg} / \mathrm{dl}$. Leuk. Lymphoma 21:85-92,1996, 10.3109/10428199609067584

17. Snider S, Bashir R, Bierman P: Neurologic complications after high-dose chemotherapy and autologous bone marrow transplantation for Hodgkin's disease. Neurology 44:681-684, 1994

18. Stewart DJ, Keating MJ, McCredie KB, Smith TL, Youness E, Murphy SG, Bodey GP, Freireich EJ: Natural history of central nervous system acute leukemia in adults. Cancer 47:184-196, 1981 